\title{
Performance of feedlot cattle with inclusion of live yeast in the diet
}

\author{
Desempenho de bovinos terminados em confinamento com a \\ inclusão de levedura viva na dieta alimentar
}

\author{
Edelmir Silvio Stadler Junior ${ }^{*}$; Leslei Caroline Santos ${ }^{2}$; Heloísa Godoi \\ Bertagnon $^{3}$; Maurício Paulo Virmond ${ }^{2}$; André Martins de Souza ${ }^{4}$; Ivone Yurika \\ Mizubutit $^{5}$; Giovanna Bobato Pontarolo ${ }^{1}$; Karina Petkowicz ${ }^{6}$; Mikael Neumann ${ }^{7}$
}

\begin{abstract}
The objective of this study was to evaluate the productive performance, ingestive behavior, apparent digestibility of the diet, rectal temperature, superficial thermography of skin and hull, and the carcass traits of heifers finished in confinement under the effect of inclusion of live yeasts (Saccharomyces cerevisiae as probiotic) in the diet. The treatments were: Control: diet without the inclusion of live yeasts, and Yeast: diet with the inclusion of live yeasts $\left(7 \mathrm{~g}\right.$ animal day ${ }^{-1}$, at the concentration of $10^{7}$ $\mathrm{CFU} \mathrm{g^{-1 }}$ ). The diets were composed of corn silage at a constant forage: concentrate ratio of 50: 50, on a dry matter basis. The experimental design was completely randomized, composed of two treatments and nine replicates, wherein each replicate was represented by a stall with two animals. Thirty-six heifers, $1 / 2$ blood Angus, from the same herd, with an average age of 11.9 months and an initial average body weight of $317 \mathrm{~kg}$, were used in the experiment. Supplementation of live yeasts in the diet for finishing heifers proved to be efficient in the feedlot finishing phase because it provided improvement in the apparent digestibility of DM. In relation to the productive performance, ingestive behavior, rectal temperature, superficial thermography of skin and hull and carcass traits, no statistical difference was found between the treatments. The animals have already come from the property adapted to the feedlot system, defining small challenge against the presence of live yeasts included in the experimental diet, justifying the lack of expression on some results obtained.
\end{abstract}

Key words: Apparent digestibility. Carcass traits. Ingestive behavior. Probiotic. Saccharomyces cerevisiae.

1 Médicos Veterinários., Discentes, Curso de Mestrado, Programa de Pós-Graduação em Ciências Veterinárias, Universidade Estadual do Centro-Oeste, UNICENTRO, Guarapuava, PR, Brasil. E-mail: edelmirjunior@hotmail.com; giovannabpontarolo@ hotmail.com

2 Médicos Veterinários, Me. em Ciências Veterinária, Programa de Pós-Graduação em Ciências Veterinárias, UNICENTRO, Guarapuava, PR, Brasil. E-mail: lesleicaroline@hotmail.com; mauriciov@hotmail.com

3 Médica Veterinária, Prof ${ }^{\mathrm{a}}$ Dr $^{\mathrm{a}}$, Programa de Pós-Graduação em Ciências Veterinárias, UNICENTRO, Guarapuava, PR, Brasil. E-mail: hbertagnon@hotmail.com

4 Médico Veterinário, Discente do Curso de Mestrado, Programa de Pós-Graduação em Produção Vegetal, UNICENTRO, Guarapuava, PR, Brasil. E-mail: andrems92@hotmail.com

5 Médica Veterinária, Prof ${ }^{\mathrm{a}} \operatorname{Dr}^{\mathrm{a}}$, Programa de Pós-Graduação em Ciência Animal, Universidade Estadual de Londrina, UEL, Londrina, PR, Brasil. E-mail: mizubuti@uel.br

6 Médica Veterinária, Discente de Mestrado, Programa de Pós-Graduação em Zootecnia, Universidade Estadual de Ponta Grossa, UEPG, Ponta Grossa, PR, Brasil. E-mail: petkowicz@outlook.com

7 Eng ${ }^{\circ}$ Agr ${ }^{\circ}$, Prof. Dr., Programa de Pós-Graduação em Ciências Veterinárias e Programa de Pós-Graduação em Produção Vegetal, UNICENTRO, Guarapuava, PR, Brasil.E-mail: neumann.mikael@hotmail.com

*Author for correspondence 


\section{Resumo}

O objetivo do trabalho foi avaliar o desempenho produtivo, o comportamento ingestivo, a digestibilidade aparente da dieta, temperatura retal, termografia superficial de pele e casco, e as características de carcaça de novilhas terminadas em confinamento sob efeito da inclusão de levedura viva (Saccharomyces cerevisiae na forma probiótica) na dieta alimentar. Os tratamentos foram: Controle: dieta sem a inclusão de levedura viva, e Levedura: dieta com a inclusão de levedura viva $\left(7 \mathrm{~g}\right.$ animal dia ${ }^{-1}$, na concentração de $10^{7} \mathrm{UFC}^{-1}$ ). As rações foram constituídas por silagem de milho em uma constante relação de $50 \%$ de volumoso e $50 \%$ de concentrado, na base seca. O delineamento experimental foi inteiramente casualizado, constituído de dois tratamentos e nove repetições, onde cada repetição foi representada por uma baia com dois animais. Utilizou-se no experimento 36 novilhas, $1 / 2$ sangue Angus, provenientes de mesmo rebanho, com idade média de 11,9 meses e peso vivo médio inicial de $317 \mathrm{~kg}$. A suplementação com leveduras vivas na dieta de novilhas mostrou-se eficiente na fase de terminação em confinamento por ter proporcionado melhoria na digestibilidade aparente da MS. Em relação ao desempenho produtivo, comportamento ingestivo, temperatura retal, termografia superficial de pele e casco e características de carcaça, não foi observada nenhuma diferença estatística entre os tratamentos. Os animais já vieram da propriedade adaptados ao confinamento, definindo baixo desafio frente a presença de leveduras vivas inclusas a dieta experimental, justificando a inexpressão sobre alguns resultados obtidos.

Palavras-chave: Características de carcaça. Comportamento ingestivo. Digestibilidade aparente. Probiótico. Saccharomyces cerevisiae.

\section{Introduction}

Yeasts are unicellular eukaryotic microscopic fungi, which have a worldwide distribution. Saccharomyces cerevisiae is one of the many existing yeast species, used for millennia in the production of alcohol, baking and in the fermentation process of beverages (CHAVAN; JANA, 2008). The use of yeasts in animal nutrition is also true.

When used as feed additive for ruminants as probiotic, the yeasts promote an environment of greater ruminal anaerobiosis by making use of the remaining oxygen in the medium (VARGAS; RAMÍREZ, 2016). Therefore, they modulate the bacterial flora, making cellulolytic, proteolytic and lactic acid bacteria divide more frequently, increasing in number (DAWSON, 2000), a process that can improve animal performance.

The chemical composition of the ruminal fluid and the temperature are responsible for creating an environment sometimes inhospitable to the growth and development of yeasts (VARGAS; RAMÍREZ, 2016). In view of this, it is recommended that the use of yeast as a food additive as probiotic should be provided on an ongoing basis (FRANÇA; RIGO, 2011). According to Tun et al. (2015), the fact that yeast increases the microbial activity is related to the presence of nutrients in its composition and also substances originated from these microorganisms' metabolism that are used as growth-promoting nutrients for this microbiota.

Researches have shown that the use of yeasts promotes stabilization of rumen fermentation processes, for example, during induction of subclinical acidosis in dairy cows, besides acting to reduce thermal stress (TUN et al., 2015). Similarly, the type of diet provided, coupled with the inclusion of the probiotic, may favor the growth of either fibrolytic or amylolytic bacteria, as well as lactic acid-using bacteria (CALLAWAY; MARTIN, 1997; DAWSON, 2000), and may improve the productive performance of the animal.

The use of yeasts in animal feed represents a sustainable practice, since it eliminates the use of antibiotics to modulate ruminal flora, avoiding possible residual effects in the final product. Moreover, it has the purpose of promoting a better 
digestibility of the diet by the animals, culminating in less production of waste. It also has the function of reducing the methane emission (MUTSVANGWA et al., 1992), reducing the greenhouse effect generated by the production systems.

The stabilization and the lower variation in ruminal $\mathrm{pH}$ result in a higher microbial protein production in the rumen, increase of rumen fermentation activity and nutrient degradation (GOMIDE, 2012; DIAS et al., 2014), besides minimizing the intensity of inflammatory processes, especially in nutritional challenges (high grain use or low fiber effectiveness in the diet).

There are many controversies in the literature regarding the inclusion of yeasts in the diet for ruminants, in which some authors describe satisfactory results with the inclusion, while others report no differences. In this context, many factors may influence these differences (SALVATI et al., 2015) such as the concentration and dose of the yeast supplied, strains used, type of diet and its proportion, environmental factors and the individual factors of each animal.

In this context, this study aimed to evaluate the productive performance, animal behavior, apparent digestibility of the diet, ruminal and limb temperature, and carcass traits of heifers finished in feedlot under the effect of the inclusion of live yeasts (Saccharomyces cerevisiae; SILEV, Cascavel-PR) in the diet.

\section{Material and Methods}

The experiment was carried out at the Animal Production Center (NUPRAN) at the Master's Degree in Veterinary Sciences, Sector of Agrarian and Environmental Sciences of the Universidade Estadual do Centro-Oeste (UNICENTRO), located in Guarapuava, state of Paraná. The climate of the Guarapuava region is the humid mesothernal subtropical $(\mathrm{Cfb})$, without dry season, with fresh summer and mild winter. According to the classification of Köppen, Guarapuava lies in an altitude of approximately $1,100 \mathrm{~m}$, with average annual rainfall of $1,944 \mathrm{~mm}$, average annual minimum temperature of $12.7{ }^{\circ} \mathrm{C}$ and average annual maximum temperature of $23.5{ }^{\circ} \mathrm{C}$ with relative humidity of $77.9 \%$.

The experimental procedures were previously submitted to the Committee for Ethical Conduct on the Use of Animals in Experimentation (CEUA / UNICENTRO), and approved for execution under letter 001/2017 of May 27, 2017.

The study used 36 1/2 Angus cross heifers, with an initial average weight of $317 \mathrm{~kg}$ and an initial average age of 11.9 months, and the animals were previously dewormed. The experimental design was completely randomized consisting of two treatments: Control: diet without the inclusion of live yeasts, and Yeast: diet with inclusion of live yeasts $\left(7 \mathrm{~g}\right.$ animal day ${ }^{-1}$ of SILEV, at a concentration of $10^{7} \mathrm{CFU} \mathrm{g}^{-1}$, Cascavel-PR) and nine replicates. The animals were housed in semi-roofed stalls (two animals per stall) and the criterion for their distribution in the experimental units (stalls) was their initial weight. Each stall was an experimental unit, and the average weight difference between treatments was $1.8 \mathrm{~kg}$.

The product used was Silev, produced in Brazil by the company Sachar Feeds. It is a functional ingredient with probiotic action obtained by the presence of the yeast Saccharomyces cerevisiae with minimum guarantee levels of $10^{7} \mathrm{CFU} \mathrm{g}^{-1}$. The strain used was ATCC9080.

The experiment lasted 105 days for finishing the animals in feedlot, with three evaluation periods of 28 days and one period of 21 days. Before the onset of the experiment, the animals were adapted to the diet and facilities. The animals were fed twice a day at $06 \mathrm{~h} 00 \mathrm{a} . \mathrm{m}$. and $05 \mathrm{~h} 30 \mathrm{p} . \mathrm{m}$.

Voluntary food intake was recorded daily by weighing the amount supplied and the leftovers from the previous day, daily adjusting the intake in 
order to keep leftovers at 5\% dry matter (DM). After adjusting, the silage and concentrate were weighed and fed to the animals after being homogenized in the trough.

In addition to the intake adjustment, daily scoring of trough leftovers was performed through visual observation. The scores were assigned through scales varying from 1 to 5 , in which: $1=$ no food; $2=$ spread food, most part of the trough apparent; 3 = thin and uniform layer at the bottom of trough; $4=$ trough with food $(20 \%$ of the amount provided in the previous meal); $5=$ full trough (greater than $50 \%$ of the amount provided in the previous meal).

The facilities consisted of 18 feedlot stalls with an area of $15 \mathrm{~m}^{2}$ each $(2.5 \mathrm{~m} \times 6.0 \mathrm{~m})$. Each stall had a concrete feeder measuring $2.30 \mathrm{~m}$ in length, 0.60 $\mathrm{m}$ in width and $0.35 \mathrm{~m}$ in depth and a metal drinking fountain controlled by automatic float.

Diets were composed of corn silage at a constant forage: concentrate ratio of 50: 50, on a dry matter basis, with or with inclusion of live yeasts. The concentrate used consisted of soybean meal, wheat bran, malt radicle, calcitic limestone, dicalcium phosphate, cattle urea, vitamin and mineral premix and common salt.

Samples of corn silage and concentrate were taken to a forced air oven at $55{ }^{\circ} \mathrm{C}$ for 72 hours to determine the partially dry matter content. The predried samples were ground in a Wiley mill with a $1 \mathrm{~mm}$ diameter sieve and subsequently subjected to determinations of dry matter (DM), mineral matter (MM), ether extract (EE) and crude protein (CP) according to techniques described in AOAC (1995). Neutral detergent fiber (NDF) contents were obtained according to the method of Van Soest et al. (1991) with thermostable $\alpha$-amylase and acid detergent fiber (ADF), according to Goering and Van Soest (1970). The total digestible nutrient (TDN) contents were calculated according to the equations proposed by Weiss et al. (1992). For the determination of the total dry matter, the samples were taken to an oven at $105^{\circ} \mathrm{C}$ for 16 hours (SILVA; QUEIROZ, 2009) and for determination of $P$ and $\mathrm{Ca}$ contents, analyses were performed according to the methodology described by Tedesco et al. (1995).

Table 1 lists the chemical composition of the feed used in animal feeding and the average nutritional values of the experimental diets, on a total dry matter basis.

Table 1. Chemical composition of feed and mean values of the experimental diet, on a total dry matter basis.

\begin{tabular}{lccc}
\hline Parameter & Corn silage & Concentrate & Experimental diet $^{1}$ \\
\hline Dry matter, \% & 33.83 & 90.40 & 62.12 \\
Mineral matter, \% DM & 2.51 & 6.36 & 4.44 \\
Crude protein, \% DM & 8.44 & 20.20 & 14.32 \\
Ether extract, \% in DM & 2.65 & 2.05 & 2.35 \\
Neutral detergent fiber, \% DM & 46.14 & 31.47 & 38.80 \\
Acid detergent fiber, \% DM & 25.98 & 13.08 & 19.53 \\
Lignin, \% DM & 8.43 & 4.73 & 6.58 \\
Total digestible nutrients, \% & 68.66 & 78.68 & 74.17 \\
Ca, \% & 0.14 & 1.67 & 0.91 \\
$\mathrm{P}, \%$ & 0.22 & 0.58 & 0.40 \\
\hline
\end{tabular}

${ }^{1}$ Premix guarantee level per kg of concentrate: vit. A: 16000 IU; vit D3: 2000 IU; vit. E: 25 IU; S: 0.36 g; Mg: 0.74 g; Na: 3.6 g; Co: $0.52 \mathrm{mg}$; Cu: $22.01 \mathrm{mg}$; F: $18.00 \mathrm{mg}$; I: $1.07 \mathrm{mg}$; Mn: $72.80 \mathrm{mg}$; Se: $0.64 \mathrm{mg}$; and Zn: $95.20 \mathrm{mg}$. 
In each feedlot period, silage samples were collected for the counting of molds and yeasts. The analyses were carried out in an accredited laboratory at CGCRE-INMETRO where the collection, transportation and testing were performed according to IN 62 of August 26, 2003 MAPA. The mean of the values found were $4.533 \mathrm{CFU} \mathrm{g}^{-1} \log 10$.

Performance evaluations were performed every 28 days in the first three periods, and every 21 days in the fourth and last period, totalizing four evaluation periods (105 evaluation days). These evaluations were carried out under solid fasting for 12 hours, in order to carry out the individual weighing of the animals. The variables evaluated were body weight (BW), average dry matter intake, expressed in $\mathrm{kg}$ animal day ${ }^{-1}$ (DMID), dry matter intake average, expressed as percentage body weight (DMIP), daily average weight gain (DAG, $\left.\mathrm{kg} \mathrm{day}^{-1}\right)$ and feed efficiency (FE, $\mathrm{kg} \mathrm{kg}^{-1}$ ).

DMID was measured by the difference between the daily amount of food supplied and the amount of leftovers from the previous day. DMIP was obtained by the ratio of DMID to the average BW of the period, multiplied by 100 (DMIP $=$ DMID $\div$ $\mathrm{BW} * 100)$. DAG was calculated by the difference between the final $\mathrm{BW}\left(\mathrm{BW}_{\mathrm{f}}\right)$ and the initial $\mathrm{BW}$ $\left(\mathrm{BW}_{\mathrm{i}}\right)$ of the experimental period divided by the evaluated days $\left(\mathrm{DAG}=\mathrm{BW}_{\mathrm{f}}-\mathrm{BW}_{\mathrm{i}} \div 28\right.$ or $\mathrm{DAG}=$ $\mathrm{BW}_{\mathrm{f}}-\mathrm{BW}_{\mathrm{i}} \div 21$, in this case, the fourth period). $\mathrm{FE}$ was obtained by the ratio of DAG to DMID (FE = $\mathrm{DAG} \div$ DMID).

The ingestive behavior analysis was performed in two moments in a continuous time of 48 hours. At the end of the first to the second period ( $1{ }^{\text {st }}$ moment), and at the end of the third to the fourth period ( $2^{\text {nd }}$ moment), starting at $12 \mathrm{~h} 00$ p.m. on the first day and ending at $12 \mathrm{~h} 00 \mathrm{p} . \mathrm{m}$. on the third day of evaluation at both times. The observations were performed by seven observers per shift for 48 hours in a rotational system every 6 hours, and the readings were taken at regular intervals of 3 minutes. Data of ingestive behavior, represented by idle, rumination, water and feed intake were expressed in hours day ${ }^{-1}$. The frequency of occurrence of each activity, expressed in number of times day $^{-1}$, were also observed, following the same methodology.

On the same days that the ingestive behavior was evaluated, at the end of each shift, the total of feces produced in each stall was collected from the floor and weighed. $450 \mathrm{~g}$ of the total produced was taken and sent to the freezer. After four shifts (24h), stool samples were homogenized and weighed $300 \mathrm{~g}$ for DM determination. It was also quantified the daily food intake through the control of leftovers of these two days. Samples of the diets and feces were dried in a forced air oven at $55{ }^{\circ} \mathrm{C}$ to constant weight, and corrected for total dry matter at $105{ }^{\circ} \mathrm{C}$. The DM of leftovers and feces from each experimental unit were determined using the same procedures adopted in the diet analysis.

The apparent digestibility coefficient (DC) of $\mathrm{DM}$ of the experimental diets were determined according to the following formula: DC $(\%)=[(\mathrm{g}$ nutrient ingested - g nutrient excreted $) \div \mathrm{g}$ nutrient ingested] x 100 .

In order to evaluate the influence of yeast on inflammatory conditions or clinical signs of disease, the temperature of the left anterior limb (hull region) and the central superficial skin region of the rumen of the animals were measured twice a week at times pre-established ( $02 \mathrm{~h} 00$ p.m.) with a FLUKE infrared camera, model Ti100. At the end of each experimental period, upon weighing, the rectal temperature was also measured with a Bioland digital thermometer.

During the experiment (105 days), the feces score of each stall was graded daily by means of visual observation. The feces were graded by means of scores, varying from 1 to 5 , in which: 1 = liquid feces, no consistency; 2 = loose feces, with few undulations, no shape definition; 3 = pasty feces with $1-1.5 \mathrm{~cm}$ high piles with 2 to 4 concentric rings; $4=$ little liquid feces with $5-7.5 \mathrm{~cm}$ high piles; $5=$ hardened feces with piles higher than 7.6 
centimeters, based on the methodology adapted from Looper et al. (2001) and Ferreira et al. (2013).

At the end of the confinement, animals were solid-fasted for 12 hours for weighing to obtain the weight of the fourth period. After this, the animals were fed and weighed again, before the shipment to the slaughterhouse, obtaining the farm weight. The carcass gain during the feedlot period (CGF) expressed in $\mathrm{kg}$ was obtained by the difference between the hot carcass weight at slaughter and the initial body weight $\left(\mathrm{BW}_{\mathrm{i}}\right)$ of the animals under theoretical carcass yield of $50 \%$. On the basis of the 105-day confinement period, the average carcass gain (ACG), expressed in $\mathrm{kg} \mathrm{day}^{-1}$, was also calculated, which is obtained by the CG-BW ratio, as well as the efficiency of conversion of dry matter consumed into carcass (ECC), expressed in $\mathrm{kg}$ DM $\mathrm{kg}$ carcass $^{-1}$, and the efficiency of conversion of weight gain into carcass, which is obtained by the ratio of ACG to DAG (ACG $\div$ DAG), expressed in $\%$. For the calculations, we used the values of hot carcass weight.

In the carcasses, four development measures were taken: carcass length, which is the distance between the medial cranial edge of the pubic bone and the medial cranial edge of the first rib; arm length, which is the distance between the tuberosity of the olecranon and the radiocarpal joint; arm perimeter, obtained in the median region of the arm encircling it with a measuring tape; and the thigh thickness, measured by means of a compass, perpendicular to the carcass length, taking the greatest distance between the cut that separates the two half carcasses and the lateral thigh muscles, according to the methodologies suggested by Muller (1987).

For the evaluated parameters, the experimental design was in randomized blocks, composed of two treatments, with nine replicates, wherein each replicate corresponded to a stall with two animals. Data collected for each variable were tested by analysis of variance with a comparison of mean values at $5 \%$ significance, through the SAS software (1993). The analysis of each variable followed the statistical model: $\mathrm{Y}_{\mathrm{ij}}=\mu+\mathrm{S}_{\mathrm{i}}+\mathrm{B}_{\mathrm{j}}+$ $E_{i j k}$; Where: $Y_{i j}=$ Dependent variables; $\mu=$ Overall mean of all observations; $S_{i}=$ Effect of live yeasts supplementation of order " $i$ "; $B_{j}=$ effect of block of order " $\mathrm{j}$ " and $\mathrm{E}_{\mathrm{ij}}=$ Residual random effect.

\section{Results and Discussion}

Table 2 lists the mean values of DAG, DMI expressed in $\mathrm{kg}$ day $^{-1}$ or per $100 \mathrm{~kg}$ body weight and FE, wherein it can be verified that the supplementation with live yeasts did not promote $(\mathrm{P}>0.05)$ improvements in performance of the animals, regardless of the feedlot phase, presenting mean values at 105 days of finishing of $1.200 \mathrm{~kg}$ day $^{-1}, 9.17 \mathrm{~kg} \mathrm{day}^{-1}, 2.40 \%$ body weight and 0.131 $\mathrm{kg} \mathrm{kg}^{-1}$, respectively.

Neumann et al. (2013) worked with whole feedlot steers receiving a diet based on corn silage and protein nucleus, using live yeasts in the diet at $8 \mathrm{~g}$ animal day ${ }^{-1}$, and found no difference $(\mathrm{P}>0.05)$ for DMI expressed in $\mathrm{kg} \mathrm{day}^{-1}$ and per $100 \mathrm{~kg}$ body weight. On the other hand, there was a difference $(\mathrm{P}<0.05)$ favorable to the yeast for DGA (1.235 vs. $\left.1.099 \mathrm{~kg} \mathrm{day}^{-1}\right)$ and for feed conversion (7.22 vs. $7.95 \mathrm{~kg}$ DM ingested per $\mathrm{kg}$ of weight gain).

Gattas et al. (2008) with male bovines and Vyas et al. (2014) beef heifers receiving a 50:50 forage:concentrate ratio using live yeasts as a feed additive, found no difference for DMI and DGA of the animals.

According to Broadway et al. (2015), the arrival of the animals to the feedlot is considered critical due to stress, making the animals susceptible to respiratory and/or metabolic diseases, when they show lower rates of dry matter intake and reduced animal performance. Considering that the animals used in the present study were already being prepared with sanitary and nutritional protocols to favor the beginning of the feedlot finishing phase, it is suggested that the lack of sigfnicance of results found for the use of yeast may be linked to this. 
Table 2. Daily average weight gain (DAG), dry matter intake (DMI) expressed in $\mathrm{kg}$ day ${ }^{-1}$ or per $100 \mathrm{~kg}$ body weight and feed efficiency (FE) of heifers finished in feedlot with live yeasts included in the diet.

\begin{tabular}{llllll}
\hline \multirow{2}{*}{ Parameter } & \multicolumn{2}{c}{ Experimental diet } & Mean & P value & SEM \\
\cline { 2 - 5 } & Control & Yeast & & & \\
\hline DAG, kg day & -1 \\
0 to 28 days & & & & & \\
0 to 56 days & 1.232 & 1.147 & 1.189 & 0.2996 & 0.0383 \\
0 to 84 days & 1.139 & 1.074 & 1.107 & 0.3682 & 0.0337 \\
0 to 105 days & 1.185 & 1.171 & 1.178 & 0.7610 & 0.0212 \\
DMID, kg day ${ }^{-1}$ & 1.197 & 1.204 & 1.200 & 0.8514 & 0.0189 \\
0 to 28 days & & & & & \\
0 to 56 days & 8.85 & 8.51 & 8.68 & 0.4153 & 0.1972 \\
0 to 84 days & 8.96 & 8.68 & 8.82 & 0.5035 & 0.1973 \\
0 to 105 days & 9.16 & 8.91 & 9.03 & 0.5356 & 0.1956 \\
DMIP, $\%$ body weight & 9.25 & 9.08 & 9.17 & 0.6582 & 0.1863 \\
0 to 28 days & & & & & \\
0 to 56 days & 2.61 & 2.55 & 2.58 & 0.5192 & 0.0502 \\
0 to 84 days & 2.53 & 2.49 & 2.51 & 0.6767 & 0.0475 \\
0 to 105 days & 2.48 & 2.45 & 2.46 & 0.7204 & 0.0449 \\
FE (DGA:DMID), $\mathrm{kg} \mathrm{kg}{ }^{-1}$ & 2.41 & 2.39 & 2.40 & 0.8636 & 0.0407 \\
0 to 28 days & & & & & \\
0 to 56 days & 0.140 & 0.136 & 0.138 & 0.7659 & 0.0061 \\
0 to 84 days & 0.127 & 0.124 & 0.126 & 0.7002 & 0.0039 \\
0 to 105 days & 0.129 & 0.131 & 0.130 & 0.7047 & 0.0024 \\
\hline
\end{tabular}

Mean values in the same row followed by different lowercase letters are significantly different from each other by F-test at $5 \%$. SEM: Standard error of the mean.

There was no significant interference $(\mathrm{P}>0.05)$ from live yeasts supplementation regarding the average daily carcass gain, conversion efficiency of consumed dry matter into carcass and consumed efficiency of weight gain into carcass, with mean values of $79.92 \mathrm{~kg}, 0.761 \mathrm{~kg} \mathrm{day}^{-1}, 63.57 \%$ and

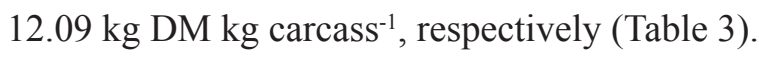

Table 3. Average carcass gain, expressed in $\mathrm{kg} \mathrm{day}^{-1}$ (ACG) and in $\mathrm{kg}$ equivalent to the total feedlot period (CGF), efficiency of conversion of dry matter consumed into carcass (ECC) and conversion efficiency of weight gain into carcass (ACG DAG ${ }^{-1}, \%$ ) of heifers finished in feedlot with live yeasts included in the diet.

\begin{tabular}{|c|c|c|c|c|c|}
\hline \multirow[t]{2}{*}{ Parameters } & \multicolumn{2}{|c|}{ Experimental diet } & \multirow[t]{2}{*}{ Mean } & \multirow[t]{2}{*}{$P$ value } & \multirow[t]{2}{*}{ SEM } \\
\hline & Control & Yeast & & & \\
\hline CGF, kg & 80.42 & 79.41 & 79.92 & 0.7973 & 1.9026 \\
\hline ACG, $\mathrm{kg}_{\text {day }}{ }^{-1}$ & 0.766 & 0.756 & 0.761 & 0.7945 & 0.0182 \\
\hline $\mathrm{ACG} \mathrm{DAG}^{-1}, \%$ & 64.12 & 63.03 & 63.57 & 0.5923 & 0.9754 \\
\hline ECC, $\mathrm{kg}$ of DM kg carcass ${ }^{-1}$ & 12.14 & 12.04 & 12.09 & 0.8479 & 0.2496 \\
\hline
\end{tabular}

Mean values in the same row followed by different lowercase letters are significantly different from each other by F-test at $5 \%$. SEM: Standard error of the mean. 
The lack of difference between the treatments for these parameters is related to the type of diet provided to the animals, supplied in the same proportions for all (50\% corn silage and 50\% concentrate), and also because they are homogenous animals, from the same category, subjected to the same environmental and management conditions.

When analyzing Table 4, it can be seen that the dry matter content of feces was not affected by the supplementation of live yeasts. In general, the apparent digestibility of dry matter improved $(\mathrm{P}<0.05)$ with the supplementation of live yeasts (72.71\% versus $71.32 \%)$, resulting from the lower $(\mathrm{P}<0.05)$ production of feces $\left(\mathrm{kg}\right.$ day $\left.^{-1}\right)$ both in dry matter (2.44 vs. $\left.2.64 \mathrm{~kg} \mathrm{day}^{-1}\right)$ and in natural material (2.96 vs. $14.23 \mathrm{~kg} \mathrm{day}^{-1}$ ) in animals supplemented with live yeasts.

Table 4. Feces production in $\mathrm{kg} \mathrm{day}^{-1}$, natural basis or dry basis, dry matter content of feces and apparent digestibility of dry matter of the diet of heifers finished in feedlot with live yeasts included in the diet, according to the feedlot period.

\begin{tabular}{|c|c|c|c|}
\hline \multirow[t]{2}{*}{ Experimental diet } & \multicolumn{2}{|c|}{ Feedlot period } & \multirow[t]{2}{*}{ Mean } \\
\hline & $1^{\text {st }}$ Period & $3^{\text {rd }}$ Period & \\
\hline & \multicolumn{3}{|c|}{ Feces production, $\mathrm{kg} \mathrm{NM} \mathrm{day}^{-1}$} \\
\hline Control & 13.93 & 14.53 & $14.23 \mathrm{~A}$ \\
\hline Yeast & 12.26 & 13.65 & $12.96 \mathrm{~B}$ \\
\hline \multirow[t]{2}{*}{ Mean } & 13.09 & 14.09 & \\
\hline & \multicolumn{3}{|c|}{ Dry matter of feces, $\%$} \\
\hline Control & 18.56 & 18.52 & 18.54 \\
\hline Yeast & 19.02 & 18.74 & 18.88 \\
\hline \multirow[t]{2}{*}{ Mean } & 18.79 & 18.63 & \\
\hline & \multicolumn{3}{|c|}{ Feces production, kg DM day ${ }^{-1}$} \\
\hline Control & 2.58 & 2.69 & $2.64 \mathrm{~A}$ \\
\hline Yeast & 2.32 & 2.55 & $2.44 \mathrm{~B}$ \\
\hline \multirow[t]{2}{*}{ Mean } & 2.45 & 2.62 & \\
\hline & \multicolumn{3}{|c|}{ Apparent digestibility of DM, \% } \\
\hline Control & 70.30 & 72.34 & $71.32 \mathrm{~B}$ \\
\hline Yeast & 72.14 & 73.28 & $72.71 \mathrm{~A}$ \\
\hline Mean & $71.22 \mathrm{~b}$ & $72.81 \mathrm{a}$ & \\
\hline
\end{tabular}

Mean values followed by different lowercase letters, in the same row, or followed by different uppercase letters, in the same column, are significantly different from each other by F-test at 5\%. SEM: Standard error of the mean.

In the comparison between the stages of confinement evaluation, regardless of the presence of yeast, the dry matter digestibility $(\mathrm{P}<0.05)$ was improved with advancing feedlot period, whereas other parameters remained stable $(\mathrm{P}>0.05)$.

The improvement observed in the dry matter digestibility by the influence of live yeasts can be justified by the maintenance of rumen health, stimulating the immune system and preventing injuries in the digestive tract due to the action of mannan oligosaccharides, $\beta$-glucans and secondly by their auxiliary potential as a substrate for the growth of ruminal microorganisms, among them fibrolytic bacteria, providing greater digestion (TUN et al., 2015). 
Live yeasts at the rumen level consume the remaining oxygen in the rumen, obtained through feed, creating a more anaerobic environment, favoring the multiplication of desirable microorganisms to obtain better animal performance (NICODEMO, 2001) and also act to improve the adhesion of these organisms to the food favoring its breakdown (SARTORI, 2016). Among this microbiota, there are the fibrolytic bacteria, which, when replicated, lead to the greater use of the fiber portion (effective NDF) of the diet, thus improving its digestibility (DING et al., 2014). Bitencourt et al. (2011) reported a tendency of greater apparent digestibility of the fiber with the use of yeasts in the diet, however they observed no variations in ruminal $\mathrm{pH}$.

A study conducted by Callaway and Martin (1997) found that yeast products improved the total digestibility of nutrients. Ponce et al. (2012) report that the yeast extract provides an improvement in the ruminal microbial flora, and Gomide (2012) reinforces that the use of live yeasts concretizes a greater development of fibrolytic bacteria, providing a positive response on microbial protein synthesis and digestion. In addition to the fact that yeast supplementation causes a better apparent digestibility of DM, this may prove to be environmentally and economically sustainable, since it reduces the excretion of waste in the environment (pollutants), and culminates in a better use of the diet by the animal.

The ingestive behavior data in Table 5 show that the time spent in food consumption, water intake, rumination and idle, on average, was not altered $(\mathrm{P}>0.05)$ by the supplementation of live yeasts. Neumann et al. (2013) also verified no differences for the same ingestive behavioral activities in the presence or absence of yeasts in the diet.

Table 5. Ingestive behavior (hours day ${ }^{-1}$ ) of heifers finished in feedlot with live yeasts included in the diet, according to the finishing phase.

\begin{tabular}{lccc}
\hline Experimental diet & \multicolumn{2}{c}{ Feedlot finishing phase } & \multirow{2}{*}{ Mean } \\
\cline { 2 - 3 } & $1^{\text {st }}$ phase & $2^{\text {nd }}$ phase & \\
\cline { 2 - 3 } Control & 3.09 & Consuming food, hours day ${ }^{-1}$ & 3.18 \\
Yeast & 3.18 & 3.27 & 3.28 \\
Mean & 3.13 & 3.38 & \\
\hline & & 3.33 & 0.26 \\
Control & 0.27 & Consuming water, hours day ${ }^{-1}$ & 0.26 \\
Yeast & 0.26 & 0.24 & \\
Mean & 0.27 & 0.26 & 5.84 \\
\hline & & 0.25 & 5.86 \\
Control & 5.50 & Rumination, hours day & \\
Yeast & 5.29 & 6.18 & 14.78 \\
Mean & $5.40 \mathrm{~b}$ & 6.42 & 14.61 \\
\hline & & 6.30 a & \\
Control & 15.21 & Idle, hours day & \\
Yeast & 15.25 & 14.34 & 13.96 \\
Mean & $15.23 \mathrm{a}$ & $14.15 \mathrm{~b}$ & \\
\hline
\end{tabular}

Mean values followed by different lowercase letters, in the same row, or followed by different uppercase letters, in the same column, are significantly different from each other by F-test at $5 \%$. 
In the analysis of the feedlot evaluation moments, the times dedicated to food and water intake were similar $(\mathrm{P}>0.05)$, while for rumination and idle there was alteration $(\mathrm{P}<0.05)$, regardless of the supplementation of live yeasts. This is in agreement with Table 2, wherein with advancing feedlot periods the animals increase DMI and ruminate more. In the initial feedlot finishing phase, they dedicated less time to rumination (5.40 vs. 6.30 hours day ${ }^{-1}$ ) and longer time to idleness (15.23 vs. 14.15 hours day $\left.{ }^{1}\right)$ compared to the final phase, independent of the supplementation with live yeasts.
When evaluating the ingestive behavior expressed in the frequency of activities in times day $^{-1}$ (Table 6), in the same way, it can be observed that there was no significant difference $(\mathrm{P}>0.05)$ in the overall mean between the animals treated or not with live yeasts. On the other hand, feeding, water intake and non-ingestive oral behavior frequency showed difference $(\mathrm{P}<0.05)$ with advancing feedlot, presenting higher frequencies at the beginning and lower at the end, since the animals became better adapted to the environment and management employed.

Table 6. Ingestive behavior, represented by the frequency of activities developed (times day ${ }^{-1}$ ), of heifers finished in feedlot with live yeasts included in the diet, according to the finishing phase.

\begin{tabular}{|c|c|c|c|}
\hline \multirow[t]{2}{*}{ Experimental diet } & \multicolumn{2}{|c|}{ Feedlot finishing phase } & \multirow[t]{2}{*}{ Experimental diet } \\
\hline & $1^{\text {st }}$ phase & $2^{\text {nd }}$ phase & \\
\hline & \multicolumn{3}{|c|}{ Feed, times day ${ }^{-1}$} \\
\hline Control & 20.7 & 18.8 & 19.8 \\
\hline Yeast & 22.0 & 18.8 & 20.4 \\
\hline \multirow[t]{2}{*}{ Mean } & $21.4 \mathrm{a}$ & $18.8 \mathrm{~b}$ & \\
\hline & \multicolumn{3}{|c|}{ Water consumption, times day ${ }^{-1}$} \\
\hline Control & 8.9 & 6.4 & 7.7 \\
\hline Yeast & 8.9 & 6.8 & 7.9 \\
\hline \multirow[t]{2}{*}{ Mean } & $8.9 \mathrm{a}$ & $6.6 \mathrm{~b}$ & \\
\hline & \multicolumn{3}{|c|}{ Solid excretions, times day ${ }^{-1}$} \\
\hline Control & 7.4 & 7.5 & 7.5 \\
\hline Yeast & 6.9 & 6.2 & 6.6 \\
\hline \multirow[t]{2}{*}{ Mean } & 7.2 & 6.8 & \\
\hline & \multicolumn{3}{|c|}{ Liquid excretions, times day ${ }^{-1}$} \\
\hline Control & 5.6 & 4.9 & $5.3 \mathrm{~A}$ \\
\hline Yeast & 5.1 & 4.4 & $4.8 \mathrm{~A}$ \\
\hline \multirow[t]{2}{*}{ Mean } & 5.3 & 4.6 & \\
\hline & \multicolumn{3}{|c|}{ Non-ingestive oral behavior, times day ${ }^{-1}$} \\
\hline Control & 5.4 & 2.7 & 4.1 \\
\hline Yeast & 6.0 & 3.8 & 4.9 \\
\hline \multirow[t]{2}{*}{ Mean } & $5.7 \mathrm{a}$ & $3.3 \mathrm{~b}$ & \\
\hline & \multicolumn{3}{|c|}{ Daily feces score } \\
\hline Control & 2.89 & 2.92 & 2.91 \\
\hline Yeast & 3.03 & 2.94 & 2.99 \\
\hline Mean & 2.96 & 2.93 & \\
\hline
\end{tabular}

Mean values followed by different lowercase letters, in the same row, or followed by different uppercase letters, in the same column, are significantly different from each other by F-test at $5 \%$. 
Working with live yeasts, Devries and Chevaux (2014) observed that animals receiving the treatment had shorter meals with a shorter time interval between one meal and another, culminating in more daily meals, which the authors attributed to the fact that the yeasts improve the fermentation process promoted by the stabilization of ruminal $\mathrm{pH}$.

Table 7 lists the carcass data, showing that, in the general, the parameters related to body weight at slaughter, hot carcass weight, carcass yield, fat thickness, carcass length, thigh thickness and arm perimeter did not differ significantly $(\mathrm{P}>0.05)$ between the treatments, with mean values of 444.8 $\mathrm{kg}, 234.9 \mathrm{~kg}, 52.8 \%, 5.1 \mathrm{~mm}, 124.4 \mathrm{~cm}, 17.9 \mathrm{~cm}$ and $38.4 \mathrm{~cm}$, respectively.

Studies conducted by Neumann et al. (2013) with young animals similar to those used in the present study found that the observed values were similar to the parameters evaluated, evidencing that the addition of live yeasts in the diet bring no direct benefits to the quantitative carcass characteristics.

Table 7. Carcass traits of heifers finished in feedlot with live yeasts included in the diet.

\begin{tabular}{|c|c|c|c|c|c|}
\hline \multirow{2}{*}{ Parameter } & \multicolumn{2}{|c|}{ Experimental diet } & \multirow{2}{*}{ Mean } & \multirow{2}{*}{$P$ value } & \multirow{2}{*}{ SEM } \\
\hline & Control & Yeast & & & \\
\hline Body weight at slaughter $(\mathrm{kg})$ & 446.5 & 443.0 & 444.8 & 0.4914 & 2.4637 \\
\hline Hot carcass weight $(\mathrm{kg})$ & 235.4 & 234.3 & 234.9 & 0.7588 & 1.9212 \\
\hline Carcass yield $(\%)$ & 52.72 & 52.89 & 52.80 & 0.6317 & 0.1761 \\
\hline Fat thickness (mm) & 5.3 & 4.8 & 5.1 & 0.4904 & 0.3101 \\
\hline Carcass length (cm) & 124.6 & 124.2 & 124.4 & 0.7458 & 0.3305 \\
\hline Thigh thickness (cm) & 18.1 & 17.8 & 17.9 & 0.5251 & 0.1668 \\
\hline Arm perimeter $(\mathrm{cm})$ & 38.6 & 38.2 & 38.4 & 0.4088 & 0.2550 \\
\hline
\end{tabular}

Mean values followed by different lowercase letters, in the same row, are significantly different from each other by F-test at $5 \%$. SEM: Standard error of the mean.

Corroborating the present study data, Neumann et al. (2013) also registered no improvements in the carcass, however observed that the use of a yeast culture with prebiotic action provided a reduction in the shear force of meat, and this is probably because the yeast culture provides an increased production of propionate in the rumen, which is converted to glucose in the liver. Based on this, it is suggested that glucose is the preferred carbon source for intramuscular fatty acid synthesis and is transformed in adipocytes (SMITH; CROUSE, 1984).

Independent of the treatments evaluated in the present study, an adequate carcass yield was found, presenting an average of $52.80 \%$ and a carcass that met the requirements of subcutaneous fat cover imposed by the meat Market ( 3 to $6 \mathrm{~mm}$ ), with the aim of avoiding quantitative and qualitative losses of the product. Similar studies using cross heifers have similar carcass yield values, varying from $50.9 \%$ to $53 \%$ on average (MARQUES et al., 2000; SOUZA et al., 2000; MARQUES et al., 2001; MULLER et al., 2005).

Table 8 presents feces scores and trough scores at $28,56,84$ and 105 days of feedlot of heifers receiving or not live yeasts included in the diet. There was no difference $(\mathrm{P}>0.05)$ between treatments. 
Table 8. Scores of leftovers in the trough and feces of heifers finished in confinement with live yeasts included in the diet.

\begin{tabular}{|c|c|c|c|c|c|}
\hline \multirow{2}{*}{ Parameter } & \multicolumn{2}{|c|}{ Experimental diet } & \multirow{2}{*}{ Mean } & \multirow{2}{*}{$P$ value } & \multirow{2}{*}{ SEM } \\
\hline & Control & Yeast & & & \\
\hline \multicolumn{6}{|l|}{ Feces score } \\
\hline 0 to 28 days & 2.8 & 2.9 & 2.9 & 0.1038 & 0.024 \\
\hline 0 to 56 days & 2.8 & 2.9 & 2.9 & 0.3972 & 0.019 \\
\hline 0 to 84 days & 2.8 & 2.8 & 2.8 & 0.1690 & 0.015 \\
\hline 0 to 105 days & 2.8 & 2.9 & 2.9 & 0.1950 & 0.012 \\
\hline \multicolumn{6}{|l|}{ Trough score } \\
\hline 0 to 28 days & 2.4 & 2.3 & 2.4 & 0.3141 & 0.067 \\
\hline 0 to 56 days & 2.4 & 2.4 & 2.4 & 0.2367 & 0.039 \\
\hline 0 to 84 days & 2.4 & 2.3 & 2.4 & 0.1175 & 0.032 \\
\hline 0 to 105 days & 2.5 & 2.3 & 2.4 & 0.1021 & 0.033 \\
\hline
\end{tabular}

Mean values followed by different lowercase letters, in the same row, are significantly different from each other by F-test at $5 \%$. SEM: Standard error of the mean.

Table 9 lists the mean values of temperature measured in the left anterior limb, rumen and rectum of feedlot heifers receiving or not live yeasts in the diet at 28, 56, 84 and 105 days of feedlot. There was no difference $(\mathrm{P}>0.05)$ between treatments.

Table 9. Temperature of the left anterior limb, rumen temperature and rectal temperature of heifers finished in feedlot with live yeasts included in the diet.

\begin{tabular}{|c|c|c|c|c|c|}
\hline \multirow{2}{*}{ Parameter } & \multicolumn{2}{|c|}{ Experimental diet } & \multirow{2}{*}{ Mean } & \multirow{2}{*}{$P$ value } & \multirow{2}{*}{ SEM } \\
\hline & Control & Yeast & & & \\
\hline \multicolumn{6}{|c|}{ Left anterior limb, ${ }^{\circ} \mathrm{C}$} \\
\hline 0 to 28 days & 29.45 & 29.99 & 29.72 & 0.4393 & 0.335 \\
\hline 0 to 56 days & 29.26 & 29.30 & 29.27 & 0.9494 & 0.288 \\
\hline 0 to 84 days & 29.39 & 29.49 & 29.43 & 0.8608 & 0.285 \\
\hline 0 to 105 days & 29.74 & 29.83 & 29.78 & 0.8708 & 0.274 \\
\hline \multicolumn{6}{|l|}{ Rumen, ${ }^{\circ} \mathrm{C}$} \\
\hline 0 to 28 days & 35.41 & 35.93 & 35.66 & 0.0642 & 0.121 \\
\hline 0 to 56 days & 34.69 & 35.16 & 34.92 & 0.0753 & 0.102 \\
\hline 0 to 84 days & 34.45 & 34.79 & 34.61 & 0.0693 & 0.069 \\
\hline 0 to 105 days & 34.79 & 35.14 & 34.96 & 0.0690 & 0.065 \\
\hline \multicolumn{6}{|l|}{ Rectum, ${ }^{\circ} \mathrm{C}$} \\
\hline 0 to 28 days & 38.89 & 38.81 & 38.84 & 0.5358 & 0.064 \\
\hline 0 to 56 days & 38.85 & 38.81 & 38.82 & 0.7632 & 0.059 \\
\hline 0 to 84 days & 38.83 & 38.63 & 38.72 & 0.4748 & 0.132 \\
\hline 0 to 105 days & 38.78 & 38.61 & 38.69 & 0.4004 & 0.098 \\
\hline
\end{tabular}

Mean values followed by different lowercase letters, in the same row, are significantly different from each other by F-test at $5 \%$. SEM: Standard error of the mean. 
The temperature evaluated on the body surface of the animals through thermography is an assertive method of use in livestock because it allows the early detection of inflammatory diseases or other diseases that may appear subclinically. The selection of areas for evaluation in the present study (hull and region close to the rumen) was based on the fact that the main conditions found in feedlot cattle may be associated with diet, culminating in inflammatory processes in rumen and hulls. Inflammatory processes trigger immune responses in the organism reflecting in cardiovascular changes manifested in the circulatory pattern of the subcutaneous, leading to the change in body surface temperature (BERRY et al., 2003). The thermography can measure this temperature and direct a possible diagnosis of the disease.

In studies with dairy cows, using yeast supplementation, it is evident that thermal stress does not negatively interfere with animal performance because yeast improves the ruminal fermentation profile (TUN et al., 2015). Schingoethe et al. (2004) reported that when supplementing dairy cows under heat stress, they found favorable responses for feed efficiency of the animals measured as net energy in milk divided by dry matter intake, increasing by $7 \%$ in cows supplemented with yeast.

Yeasts still have many of their effects unclear in the literature, especially regarding the control of thermal stress. Autolyzed yeasts are rich in B vitamins, including niacin, which according to Zimbelman et al. (2013), is responsible for providing increased milk yield in cows subjected to thermal stress. The vitamin mentioned above, also called vitamin B3, has its effect based on promoting tegumentary vasodilation in the animal causing it to lose heat to the medium, reducing its internal temperature (ZIMBELMAN et al., 2010).

In general, the conditions established in the management of the feedlot animals provided animal well-being and comfort, which defined a small challenge against the presence of live yeasts included in the experimental diet, justifying the lack of expression on the results obtained.

Another important point to report is that the presence of yeasts in silages is true, especially when opening the silo, and the ensiled mass is exposed to oxygen (JASTER, 1994). This fact can be evidenced when counting fungi and molds in the silage supplied to the animals in the present experiment. Therefore, further studies are required to check for synergism or neutralization between environmental yeasts present in silage and yeasts supplemented in the diet.

\section{Conclusions}

The supplementation of live yeasts in the feedlot diet proved to be efficient in the finishing phase of cattle, owing the improvement in the apparent digestibility of DM, showing a sustainable practice. The conditions established in the management of the confined animals provided well-being and comfort, which defining a small challenge against the presence of live yeasts included in the experimental diet, justifying the lack of expression on performance results.

\section{References}

ASSOCIATION OF OFFICIAL ANALYTICAL CHEMISTS - AOAC. Official methods of analysis. $16^{\text {th }}$ ed. Washington: AOAC, 1995. 2000 p.

BERRY, R. J.; KENNEDY, A. D.; SCOTT, S.; KYLE, B. L.; SCHAEFER, A. L. Daily variation in the udder surface temperature of dairy cows measured by infrared thermography: potential for mastitis detection. Canadian Journal of Animal Science, Champaign, v. 83, n. 4, p. 687-693, 2003. DOI: 10.4141/A03-012

BITENCOURT, L. L.; SILVA, J. R. M.; OLIVEIRA, B. M. L.; DIAS JÚNIOR, G. S.; LOPES, F.; SIÉCOLA JÚNIOR, S.; ZACARONI, O. F.; PEREIRA, M. N. Diet digestibility and performance of dairy cows supplemented with live yeast. Scientia Agricola, Piracicaba, v. 68, n. 3, p. 301-307, 2011. DOI: 10.1590/ S0103-90162011000300005 
BROADWAY, P. R.; CARROLL, J. A.; NICOLE C.; BURDICK SANCHEZ, N. C. Live yeast and yeast cell wall supplements enhance immune function and performance in food-producing. Microorganisms, United States, v. 3, n. 3, p. 417-427, 2015. DOI: 10.3390/ microorganisms 3030417

CALLAWAY, E. S.; MARTIN, S. A. Effects of a Saccharomyces cerevisiae culture on ruminal bacteria that utilize lactate and digest cellulose. Journal of Dairy Science, Champaign, v. 80, n. 9, p. 2035-2044, 1997. DOI: $10.3168 /$ jds.S0022-0302(97)76148-4

CHAVAN, R. S.; JANA, A. Frozen dough for bread making - a review. International Journal Food Science, Technology and Nutrition, New York, v. 2, n. 1, p. 9-27, 2008.

DAWSON, K. A. Some milestones in our understanding of yeast culture supplementation in ruminants and their implications in animal productions systems. In: ANNUAL SYMPOSIUM OF NUTRITIONAL BIOTECHNOLOGY IN THE FEED AND FOOD INDUSTRIES, 16., 2000, Nicholasville. Proceedings... Nicholasville: Alltech Technical Publications, 2000. p. 473-483.

DEVRIES, T. J.; CHEVAUX, E. Modification of the feeding behavior of dairy cows through live yeast supplementation. Journal of Dairy Science, Champaign, v. 97 , n. 10 , p. $6499-6510,2014$. DOI: $10.3168 /$ jds.20148226

DIAS, A. L. G.; AZEVEDO, R. A.; FREITAS, J. A.; MICAI, B.; SILVA, T. V.; GOMES, G. C.; RIRO, E. S.; GRECO, L. F.; LEOPOLDO JUNIOR, P. M.; SANTOS, J. E. P. Effect of feed ingyeast culture (YC) on lactation performance of dairy cows fed diets differing in rumen fermentability. In: ADSA-ASAS-CSAS JOINT ANNUAL MEETING, 2014, Gainesville. Proceeding... Gainesville: University of Florida, 2014. p. 859.

DING, G.; CHANG, Y.; ZHAO, L.; ZHOU, Z.; REN, L.; MENG, Q. Effect of Saccharomyces cerevisiae on alfalfa nutrient degradation characteristics and rumen microbial population of steers fed diets with different concentrate-to-forage ratios. Journal of Animal Science and Biotechnology, China, v. 5, n. 24, p. 1-9, 2014. DOI: 10.1186/2049-1891-5-24

FERREIRA, S.; GUIMARÃES, T.; MOREIRA, K.; ALVES, V.; LEMOS, B.; SOUZA, F. Caracterização fecal de bovinos. Revista Científica Eletrônica de Medicina Veterinária, Garça, v. 11, n. 20, p. 1-22, 2013.

FRANÇA, R. A.; RIGO, E. J. Utilização de leveduras vivas (Saccharomyces cerevisiae) na nutrição de ruminantes: uma revisão. Uberaba: Cadernos de PósGraduação da FAZU, v. 2, 2011. 9 p.
GATTAS, C. B. A.; MORAIS, M. G.; ABREU, U. G. P.; LEMPP, B.; STEIN, J.; ALBERTINI, T. Z.; FRANCO, G. L. Consumo, digestibilidade aparente e ganho de peso em bovinos de corte confinados suplementados com cultura de levedura (Saccharomyhces cerevisiae cepa 1026). Ciência Animal Brasileira, Goiânia, v. 9, n. 3, p. 535-542, 2008.

GOERING, H. K.; VAN SOEST, P. J. Forage fiber analysis: apparatus reagents, procedures and some applications. Washington: [s.n.], 1970.379 p. (Agricultural Handbook).

GOMIDE, D. R. Resposta digestiva de bovinos a doses de levedura autolisada. 2012. Dissertação (Mestrado em Ciências Veterinárias) - Universidade Federal de Lavras, Lavras.

JASTER, E. Fermentation principles of legume, grass forage examined. Feedstuffs, v. 12, n. 12, p. 14-16, 1994.

LOOPER, M. L.; STOKES, S. R.; WALDNER, D. N.; JORDAN, E. R. Managing milk composition: evaluating herd potential. Cooperative extension service college of agriculture and home economics. Guide D-104. New Mexico: New Mexico State University, 2001. 35 p.

MARQUES, J. A.; PRADO, I. N.; NASCIMENTO, W. G. Avaliação do desempenho de novilhas mestiças em diferentes condições reprodutivas confinadas. In: REUNIÃO ANUAL DA SOCIEDADE BRASILEIRA DE ZOOTECNIA, 38., 2001, Piracicaba. Anais... Piracicaba, Sociedade Brasileira de Zootecnia, 2001. p. 960-962.

MARQUES, J. A.; PRADO, I. N.; ZEOULA, L. M.; ALCALDE, C. R.; NASCIMENTO, W. G. Avaliação da mandioca e seus resíduos industriais em substituição ao milho no desempenho de novilhas confinadas. Revista Brasileira de Zootecnia, Viçosa, MG, v. 29, n. 5, p. 15281536, 2000. DOI: 10.1590/S1516-35982000000500035

MULLER, L. Normas para avaliação de carcaças e concurso de carcaça de novilhos. 2. ed. Santa Maria: Universidade Federal de Santa Maria, 1987. 31 p.

MULLER, M.; PRADO, I. N.; LOBO JÚNIOR, A. R.; SCOMPARIN, V. X.; RIGOLON, L. P. Diferentes fontes de gordura sobre o desempenho e características de carcaça de novilhas de corte confinadas. Red de Revistas Científicas de América Latina y el Caribe, España y Portugal, Maringá, v. 27, n. 1, p. 131-137, 2005.

MUTSVANGWA, T.; EDWARDS, I. E.; TOPPS, J. H.; PATERSON, G. F. M. The effect of dietary inclusion of yeast culture (Yea-Sacc) on patterns of rumen fermentation, food intake and growth of intensively fed bulls. Animal Science, Liverpool, v. 55, n. 1, p. 35-40, 1992. DOI: $10.1017 / \mathrm{S} 0003356100037247$ 
NEUMANN, M.; SILVA, M. R. H.; FIGUEIRA, D. N.; SPADA, C. A.; REINEHR, L. L.; POCZYNEK, M. Leveduras vivas (Sacharomyces cerevisie) sobre o desempenho de novilhos terminados em confinamento e as características da carne e da carcaça. Revista Acadêmica: Ciências Agrárias e Ambientais, Curitiba, v. 11, n. 1, p. 75-85, 2013. DOI: 10.7213/academica.7758

NICODEMO, M. L. F. Uso de aditivos na dieta de bovinos de corte. Campo Grande: EMBRAPA Gado de Corte, 2001. 54 p. (Documentos, EMBRAPA Gado de Corte).

PONCE, C. H.; SCHUTZ, J. S.; ELROD, C. C.; ANELE, U. Y.; GALYEAN, M. L. Effects of dietary supplementation of a yeast product on performance and morbidity of newly received beef heifers. Professional Animal Scientist, New Mexico, v. 28, n. 6, p. 618-622, 2012. DOI: 10.15232/S1080-7446(15)30419-8

SALVATI, G. G. S.; MORAIS JÚNIOR, N. N.; MELO, A. C. S.; VILELA, R. R.; CARDOSO, F. F.; ARONOVICH, M.; PEREIRA, R. A. N.; PEREIRA, M. N. Response of lactating cows to live yeast supplementation during summer. Journal of Dairy Science, Champaign, v. 98, n. 6, p. 4062-4073, 2015. DOI: 10.3168/jds.2014-9215

SARTORI, E. D. Uso de levedura na alimentação de bovinos de corte: uma revisão sistemática- metanálise. 2016. Dissertação(Mestrado em Zootecnia)-Universidade Federal do Rio Grande do Sul, Porto Alegre.

SCHINGOETHE, D. J.; LINKE, K. N.; KALSCHEUR, K. F.; HIPPEN, A. R.; RENNICH, D. R.; YOON, I. Feed efficiency of mid-lactation dairy cows fed yeast culture during summer. Journal of Dairy Science, Champaign, v. 87 , n. 12 , p. $4178-4181,2004$. DOI: $10.3168 /$ jds.S00220302(04)73561-4

SILVA, D. J.; QUEIROZ, A. C. Análise de alimentos: métodos químicos e biológicos. 3. ed. 4. reimp. Viçosa: Universidade Federal de Viçosa, 2009. 235 p.

SMITH, S. B.; CROUSE, J. D. Relative contributions of acetate, lactate and glucose to lipogenesis in bovine intramuscular and subcutaneous adipose tissue. Journal of Nutrition, Texas, v. 114, n. 4, p. 792-800, 1984. DOI: $10.1093 / \mathrm{jn} / 114.4 .792$

SOUZA, A. M.; PRADO, I. N.; ALCALDE, C. R.; ZEOULA, L. M.; MARQUES, J. A. Desempenho de novilhas alimentadas com rações contendo milho ou casca de mandioca como fonte energética e farelo de algodão ou levedura como fonte proteica. Revista Brasileira de Zootecnia, Viçosa, MG, v. 29, n. 1, p. 278-287, 2000.

STATISTICAL ANALYSIS SYSTEM INSTITUTE SAS Institute. SAS/STAT user's Guide: statistics. North Caroline, 1993. v. 2, 943 p.
TEDESCO, M. J.; GIANELlO, C.; BISSANI, C. A.; BOHNEN, H.; VOLHWEISS, S. J. Análises de solo, plantas e outros materiais. 2. ed. Porto Alegre: Universidade Federal do Rio Grande do Sul, 1995. 74 p. (Boletim Técnico, 5).

TUN, H. M.; LI, S.; YOON, L.; SCOTT, M.; PLAIZIER, J. C.; KHAFIPOUR, E. Massive shotgun metagenomic sequencing reveals the potential mode of action of Saccharomyces cerevisiae fermentation product (SCFP) on rumen microbiome during subacute ruminal acidosis (SARA) in dairy cows. Journal Animal Science, Champaign, v. 93, n. 3, p. 320-321, 2015.

VAN SOEST, P. J.; ROBERTSON, J. B.; LEWIS, B. A. Symposium: carbohydrate methodology, metabolism, and nutritional implications in dairy cattle. Methods for dietary fiber, neutral detergent fiber and nonstarch polysaccharides in relation to animal nutrition. Journal of Dairy Science, Champaign, v. 74, n. 10, p. 3583-3597, 1991.

VARGAS, A. Y. V.; RAMÍREZ, J. O. H. Efectos de la pared celular de saccharomyces cerevisiae sobre pollos de engorda suplementados con alimento contaminado con aflatoxina b1 y b2. In: CONGRESO AVIESPECIALISTAS DE MÉXICO, 9., 2016, Querétaro. Proceeding... Querétaro: Memorias, 2016. p. 88-101.

VYAS, D.; UWIZEYE, A.; MOHAMMED, R.; YANG, W. Z.; WALKER, N. D.; BEAUCHEMIN, K. A. The effects of active dried and killed dried yeast on subacute ruminal acidosis, ruminal fermentation, and nutrient digestibility in beef heifers. Journal of Animal Science, Champaign, v. 92 , n. 2, p. 724-732, 2014. DOI: $10.2527 /$ jas.2013-7072

WEISS, W. P.; CONRAD, H. R.; PIERRE, N. R. S. A theoretically-based model for predicting total digestible nutrient values of forages and concentrates. Animal Feed Science and Technology, Amsterdam, v. 39, n. 1, p. 95110, 1992. DOI: 10.1016/0377-8401(92)90034-4

ZIMBELMAN, R. B.; COLLIER, R. J.; BILBY, T. R. Effects of utilizing rumen protected niacin on core body temperature as well as milk production and composition in lactating dairy cows during heat stress. Animal Feed Science and Technology, Amsterdam, v. 180, n. 1-4, p. 26-33, 2013. DOI: 10.1016/j.anifeedsci.2013.01.005

ZIMBELMAN, R. B.; BAUMGARD, L. H.; COLLIER, R. J. Effects of encapsulated niacin on evaporative heat loss and body temperature in moderately heat-stressed lactating Holstein cows. Journal of Dairy Science, Champaign, v. 93, n. 6, p. 2387-2394, 2010. DOI: $10.3168 /$ jds.2009-2557 
